\title{
USE OF CONSTRUCTION RENOVATION AND DEMOLITION WASTE IN PARTIAL REPLACEMENT OF COARSE AGGREGATE IN M20 CONCRETE
}

\author{
N. Sai Trinath Kumar ${ }^{1}$, Chava Siva ${ }^{2}$ \\ ${ }^{I}$ Student, Department of Civil Engineering, RVR \& JC College Of Engineering, Andhra Pradesh, India \\ ${ }^{2}$ Student, Department of Civil Engineering, RVR \& JC College Of Engineering, Andhra Pradesh, India
}

\begin{abstract}
Concrete is a pourable mix of cement, water, sand, and gravel that hardens into a super strong building material. In the recent decades demolition of old buildings, renovation of construction gave rise to gargantuan amounts of construction and demolition waste. Even the waste produced by industries and households got amplified. So experiments were carried out in the laboratory to scrutinize a concrete made of partial replacement of coarse aggregate with construction and demolition waste materials like ceramic tiles waste, plastic debris, crushed bricks. The resultant concrete thus produced was tested on the following parameters like compressive strength, workability, flexural strength. The results thus obtained are compared with a plain cement concrete. By using low weight materials like plastic debris we got a light weight concrete. The workability of concrete produced with construction waste when compared with plain cement concrete is not reliable but it produced a considerable increase in the compressive strength. So we have increased quantity of plastic debris and deducted some quantity of other waste, by this the workability standards are maintained. Hence by using required quantities strength and workability are acquired. Economy plays a imperative role in any construction, by partially replacing of coarse aggregate with construction and demolition waste, plastic waste the cost of construction can be reduced. These wastes can cause pollution that effects human health. Using these wastes effectively in construction activities the rate of pollution can also be controlled. Even the properties of concrete can also be improved.
\end{abstract}

Key Words: Construction and Demolition waste, Plastic Debris, Compressive Strength, Flexural Strength, Workability.

\section{INTROUCTION}

Aggregates are generally considered as inert filler materials in the concrete mix. Aggregates characteristically make up about 60 to 75 percent of the volume of a concrete mixture. It is a necessary component that defines the concrete's thermal and elastic properties and dimensional stability. By a closer look it reveals that they can influence major role in the properties of fresh and hardened concrete. Changes in gradation, maximum size, unit weight, moisture content can alter the character and performance of concrete mix. While replacing such a hard and inert material one should consider all the strength characteristics and properties of replacing material. The replaced materials should provide volume stability to the hardened concrete.

Nearly everything we do leaves behind produce some kind of waste. Households create ordinary garbage, while industrial and manufacturing process create solid and hazardous waste, construction demolition and renovation too engender some amount of waste. The waste produced per sq. $\mathrm{Km}$ of demolition is 10 times that generated during construction. The built up area is expected to swell almost five times from 21 billion sq. $\mathrm{ft}$ in 2005 to nearly 104 billion sq. ft by 2030 . The construction demolition waste include road, railway, runway construction renovation activity waste like concrete broken asphalt, paving stone, sand, pebble railway traverse and ballast. And from buildings concrete with iron and concrete without iron, roofing cover, isolation material, bricks, briquette, stones, stucco, gypsum, plastic, ceramics, metals, paper and pulp etc,. Construction waste recycle plants are now installed in various countries but they are partly solution to the waste problems.

Every material or waste produced in construction activities cannot be biodegradable or less biodegradable. Especially plastic has profuse polluting characteristics. By reusing these waste materials in the construction activities the rate of pollution can be controlled. The productive use of these waste materials represents a mean of alleviating some of the problems of solid waste management. Hence partial and full replacement of aggregates by the waste materials can conserve some ecological balance.

In this investigation, an attempt has been made to study the feasibility of using plastic debris, crushed bricks, ceramic tiles of a locally available construction waste for making a recycled aggregate concrete. We have used waste bricks, plastic debris, ceramic tiles waste that are being produced in renovation of old building in Guntur. As we got the 
materials to our hands, testing's done to know the properties of those materials. Plain cement concrete blocks are also casted and tested to compare the results with recycled aggregate concrete.. Natural coarse aggregates are replaced with crushed bricks, crushed tiles, plastic debris. Initially plastic debris of $5 \%$ is used and then after to increase the workability plastic debris is increased to $10 \%$. The test results obtained are discussed below.

Advantages of using waste materials as aggregate in concrete Indiscriminate mining of sand and other minerals and construction materials has caused extension damage to the environment, scarred rivers, made many areas to susceptible to floods and destroyed the crucial recharge zones. Natural resources and dumping areas can be saved and even helps in maintaining clean environment. The present concrete construction practice is thought unsustainable because not only it is continuing enormous amounts of stone, sand and drinking water but also two billion tonnes a year of Portland cement which releases green house gases leading to global warming. By using waste in construction activities even these problems can get some solutions.

\section{MATERIAL USED IN TESTS}

\subsection{Cement}

43 grade ordinary Portland cement with a specific gravity of 3.15 is used in experimentation. Normal consistency of the cement is found to be $26 \%$. Initial and final setting time are 95 and 240 respectively. Bulk density of $1440 \mathrm{~kg} / \mathrm{m}^{3}$.

\subsection{Coarse Aggregate}

$20 \mathrm{~mm}$ nominal size coarse aggregate having a specific gravity of 2.68 is used. The impact value and water absorption of coarse aggregates is $21.23 \%$ and $0.4 \%$.

Density of $1650 \mathrm{~kg} / \mathrm{m}^{3}$.

\subsection{Fine Aggregate}

zone III river sand with fineness modulus number of 7.86 and water absorption capacity of $0.51 \%$ and a density of $1780 \mathrm{Kg} / \mathrm{m}^{3}$.

\subsection{Ceramic tiles}

Ceramic tiles are collected from the renovated construction in Guntur. After collecting they were crushed into small particles in the laboratory. Tiles powder is separated from the crushed tiles and partially larger tiles are again crushed and were taken to the experimentation. The impact value of crushed tiles $26.84 \%$. Bulk density is $2750 \mathrm{~kg} / \mathrm{m}^{3}$.

\subsection{Plastic debris}

Plastic debris is collected from the nearby industry. The fineness modulus of plastic varied from different proportions of plastic content in the mixture. Fineness modulus of plastic is observed as 6.49 and density as 1.42 $\mathrm{kg} / \mathrm{m}^{2}$.

\subsection{Crushed bricks}

Manually crushed well burnt bricks with a compressive strength of $32.1 \mathrm{mpa}$ and fineness modulus of 7.12 were used in the experimentation. Bulk density of the crushed bricks was 2.15 . Water absorption capacity of $16.38 \%$ is observed.

\section{PROPERTIES OF CEMENT}

Table- 1

\begin{tabular}{|l|l|l|l|}
\hline Sl. No. & \multicolumn{1}{|c|}{ Property } & Value & \multicolumn{1}{|c|}{ Unit } \\
\hline 1. & Grade of cement used & 43 grade & \\
\hline 2. & Specific gravity & 3.15 & \\
\hline 3. & Fineness & 3.7 & $\%$ \\
\hline 4. & Normal consistency & 26 & $\%$ \\
\hline 5. & Initial setting time & 95 & Min \\
\hline 6. & Final setting time & 240 & Min \\
\hline 7. & Soundness & 4.3 & Mm \\
\hline 8. & Compressive strength & & \\
& $1 . \quad 3$ days & 27.16 & $\mathrm{~N} / \mathrm{mm}^{2}$ \\
& $2 . \quad 7$ days & 45.89 & $\mathrm{~N} / \mathrm{mm}^{2}$ \\
& 3. & & \\
\hline
\end{tabular}

Table -2: Mix proportions of M20 grade concrete (1:1.5:3)

\begin{tabular}{|c|c|c|c|c|c|c|c|c|c|}
\hline $\begin{array}{l}\text { S. } \\
\text { No. }\end{array}$ & $\begin{array}{ll}\text { Concrete } & \operatorname{mix} \\
\text { Proportions } & \end{array}$ & $\begin{array}{l}\text { Water } \\
(\mathrm{kg})\end{array}$ & $\begin{array}{l}\text { Cement } \\
(\mathrm{kg})\end{array}$ & $\begin{array}{l}\text { Fine } \\
\text { Aggregate } \\
(\mathrm{kg})\end{array}$ & $\begin{array}{l}\text { Coarse } \\
\text { Aggregate } \\
(\mathrm{kg})\end{array}$ & $\begin{array}{l}\text { Plastic } \\
\text { debris } \\
(\mathrm{kg})\end{array}$ & $\begin{array}{l}\text { Ceramic } \\
\text { waste } \\
(\mathrm{kg})\end{array}$ & $\begin{array}{l}\text { Crushed } \\
\text { bricks } \\
(\mathrm{kg})\end{array}$ & $\begin{array}{l}\mathrm{w} / \mathrm{c} \\
\text { ratio }\end{array}$ \\
\hline 1. & PCC & 205 & 410 & 840.16 & 1412.4 & 0 & 0 & 0 & 0.5 \\
\hline 2. & $\begin{array}{ll}100 \% & \text { crushed } \\
\text { bricks(Mix 1) } & \end{array}$ & 205 & 410 & 840.16 & 0 & 0 & 0 & 1617.84 & 0.5 \\
\hline
\end{tabular}




\begin{tabular}{|c|c|c|c|c|c|c|c|c|c|}
\hline 3. & $\begin{array}{l}100 \% \text { crushed ceramic } \\
\text { tiles(Mix 2) }\end{array}$ & 205 & 410 & 840.16 & 0 & 0 & 2354 & 0 & 0.5 \\
\hline 4. & $\begin{array}{l}5 \% \text { plastic } \\
\text { crushed bris }+50 \% \\
\text { ceramic waste (Mix } 3 \text { ) }\end{array}$ & 205 & 410 & 840.16 & 0 & 6.07 & 1059.3 & 808.92 & 0.5 \\
\hline 5. & $\begin{array}{ll}5 \% \text { plastic } & \text { debris }+40 \% \\
\text { crushed } & \text { bricks }+35 \% \\
\text { ceramic } & \text { waste }+20 \% \\
\text { coarse aggregate } & \text { (Mix } \\
\text { 4) } & \end{array}$ & 205 & 410 & 840.16 & 282.48 & 6.07 & 823.9 & 647.13 & 0.5 \\
\hline 6. & $\begin{array}{ll}5 \% \text { plastic } & \text { debris }+30 \% \\
\text { crushed } & \text { bricks }+25 \% \\
\text { ceramic } & \text { waste }+40 \% \\
\text { coarse aggregate } & \text { (Mix } \\
\text { 5) } & \end{array}$ & 205 & 410 & 840.16 & 564.96 & 6.07 & 588.5 & 485.35 & 0.5 \\
\hline 7. & $\begin{array}{ll}5 \% \text { plastic } & \text { debris }+20 \% \\
\text { crushed } & \text { bricks }+15 \% \\
\text { ceramic } & \text { waste }+60 \% \\
\text { coarse aggregate } & \text { (Mix } \\
6 \text { ) } & \end{array}$ & 205 & 410 & 840.16 & 847.44 & 6.07 & 353.1 & 323.56 & 0.5 \\
\hline 8. & $\begin{array}{l}10 \% \text { plastic debris }+50 \% \\
\text { crushed bricks+40\% } \\
\text { ceramic waste (Mix 7) }\end{array}$ & 205 & 410 & 840.16 & 0 & 12.15 & 941.6 & 808.92 & 0.5 \\
\hline 9. & $\begin{array}{l}10 \% \text { plastic debris }+40 \% \\
\text { crushed bricks }+30 \% \\
\text { ceramic waste }+20 \% \\
\text { coarse aggregate (Mix } \\
\text { 8) }\end{array}$ & 205 & 410 & 840.16 & 282.48 & 12.15 & 706.2 & 647.13 & 0.5 \\
\hline 10. & $\begin{array}{l}10 \% \text { plastic debris }+30 \% \\
\text { crushed bricks }+25 \% \\
\text { ceramic waste }+35 \% \\
\text { coarse aggregate (Mix } \\
9 \text { 9) }\end{array}$ & 205 & 410 & 840.16 & 494.34 & 12.15 & 588.5 & 485.35 & 0.5 \\
\hline 11. & $\begin{array}{l}10 \% \text { plastic debris }+25 \% \\
\text { crushed bricks }+15 \% \\
\text { ceramic waste }+50 \% \\
\text { coarse aggregate (Mix } \\
10 \text { ) }\end{array}$ & 205 & 410 & 840.16 & 706.2 & 12.15 & 353.1 & 404.46 & 0.5 \\
\hline
\end{tabular}

\section{TESTS CONDUCTED IN THE LABORATORY}

\subsection{Tests for Workability of Concrete.}

Consistency is the term very closely related to workability. To know the workability of concrete slump cone test is conducted. Workability of concrete is mainly affected by consistency i.e. wetter mixes will be more workable than drier mixes, but concrete of the same consistency may vary in workability. Slump cone dimensions are as per the Indian standards. Top diameter, bottom diameter, height are $10 \mathrm{~cm}$, $20 \mathrm{~cm}, 30 \mathrm{~cm}$ respectively. The test procedure carried out on each sample are as per [2] Indian standards recommendations of IS 1199-1959. Max slump value of $162 \mathrm{~mm}$ is obtained. The slump values obtained are tabulated below. First and second mixes have some workability failure due to that reason we have added plastic debris to increase the workability. As the waste materials which are used in replacement of aggregates are low in weight we got 2 to 3 light weight mixes.

\subsection{Compressive strength of concrete.}

Out of all tests conducted on concrete, compressive strength of concrete has utmost importance and which gives all the important characteristics of a concrete. We have casted a total of 33 concrete blocks with different proportions including PCC. Size of the concrete block $150 \mathrm{~mm} \times 150 \mathrm{~mm} \times 150 \mathrm{~mm}$ cube moulds are used for the tests. The concrete is poured in to mould and are tampered to avoid voids. After hours of duration test moulds are removed and the specimens are kept in water for curing. These specimens are tested under compressive testing machine after 7 days and 28 days after casting. $140 \mathrm{~kg} / \mathrm{cm}^{2} /$ minute load is applied on the specimen till it fails. Maximum compressive strength of $27.41 \mathrm{mpa}$ is obtained for $3^{\text {rd }}$ mix $(5 \%$ plastic debris $+50 \%$ crushed bricks+45\%crushed tiles). The test results obtained are compared with the results obtained for plain cement concrete. 


\subsection{Flexural strength of concrete}

Flexural strength is the stress in the material before it yields. It is also known as Bend strength. Flexural strength is about 10 to 20 percentage of compressive strength of concrete. The centre point loading method is used to check the flexural strength of concrete blocks. $150 \mathrm{~mm} \times 150 \mathrm{~mm} \times 700 \mathrm{~mm}$ mould is used in the test. Total of
33 blocks are casted and checked for flexural strength by centre point load test. The tests are conducted according to the Indian standard specifications of [3] IS: 516 (1959), "Indian Standard Code of Practice - Methods of Test for Strength of Concrete," Bureau of Indian Standards. The results obtained are compared with plain cement concrete.

Table -2 : Test results

\begin{tabular}{|c|c|c|c|c|c|c|}
\hline \multirow[t]{2}{*}{ S.No. } & \multirow[t]{2}{*}{ Mix } & \multirow{2}{*}{$\begin{array}{l}\text { Slump } \\
(\mathrm{mm})\end{array}$} & \multicolumn{2}{|c|}{ Compressive strength (mpa) } & \multicolumn{2}{|c|}{ Flexural strength (mpa) } \\
\hline & & & 7 days & 28 days & 7 days & 28 days \\
\hline 1. & PCC & 164 & 18.56 & 29.32 & 3.18 & 4.76 \\
\hline 2. & Mix 1 & 140 & 14.68 & 24.39 & 2.72 & 3.98 \\
\hline 3. & Mix 2 & 139 & 13.47 & 23.67 & 2.59 & 3.86 \\
\hline 4. & Mix 3 & 150 & 16.98 & 27.41 & 3.01 & 4.45 \\
\hline 5. & Mix 4 & 152 & 16.21 & 26.59 & 2.98 & 4.37 \\
\hline 6. & Mix 5 & 153 & 15.63 & 26.11 & 2.92 & 4.26 \\
\hline 7. & Mix 6 & 155 & 14.93 & 25.73 & 2.88 & 4.17 \\
\hline 8. & Mix 7 & 158 & 14.86 & 24.92 & 3.10 & 4.43 \\
\hline 9. & Mix 8 & 160 & 14.08 & 23.77 & 3.07 & 4.29 \\
\hline 10. & Mix 9 & 160 & 13.96 & 23.86 & 3.12 & 4.51 \\
\hline 11. & Mix 10 & 162 & 14.59 & 24.64 & 3.14 & 4.68 \\
\hline
\end{tabular}

\section{CONCLUSIONS}

Following conclusion is on the basis of experimental results. Cost of casting concrete with replacement of construction waste when compared to plain cement concrete is very low and the properties tested are nearly adjacent to plain cement concrete. The rate of pollution can also be controlled by using this recycled waste material. Main point to be discussed is that plastic debris has increased the workability standards of concrete while crushed bricks and crushed ceramic tiles alone could not produce a workable concrete. Density and mass of the concrete can be reduced by using plastic debris. All the values are average of three samples of the respected mix proportions.

\section{AKNOWLEDGEMENT}

We sincerely thank all the Professors and the laboratory staff who have advised us and helped us in making this project successful. We thank RVR \& JC College of Engineering Which helped in exploring our Talents.

\section{REFERENCE}

[1]. IS: 8112 (1989), "Specifications for 43-Grade Portland Cement", Bureau of Indian Standards

[2]. IS: 1199 (1959), "Indian Standard Methods of Sampling and Analysis of Concrete", Bureau of Indian Standards, New Delhi, India.

[3]. IS: 516 (1959), "Indian Standard Code of Practice Methods of Test for Strength of Concrete," Bureau of Indian Standards.

[4]. IS: 10262 (1982), "Recommended Guidelines for Concrete Mix Design", Bureau of Indian Standards.

[5]. IS: 456 (2000), "Plain and Reinforced Concrete Code of Practice", Bureau of Indian Standards

[6]. IS: 383 (1970), "Specifications for Coarse and Fine
Aggregates from Natural Sources for Concrete", Bureau of Indian Standards.

[7]. Mehta ad monterio.(1993) concrete structure, properties , and materials, prentice- hall, Inc., Englewood cliffs, NJ

[8]. SP 23 :1982, "handbook on concrete mixes", Bureau of Indian Standard, New delhi-02

[9]. R.W Davidge (1986): Mechanical behaviour of ceramics; Cambridge University Press, New York USA.

[10]. Maiti S C, Agarwal R K and Kumar Rajeesh (2006) “concrete mix proportioning' The Indian Concrete Journal, pg 23-27

[11]. Khaloo, A.R. (1995). "Crushed tile coarse aggregate concrete." Cement, Concrete, and Aggregates, 17(2), 119-125.

[12]. Lalji Prajapati, N. patel, V.V. Agarwal, "Analysis of The Strength and Durability Of The Concrete With Partially Replaced By The Ceramic Slurry Waste Powder", International Journal of Emerging Technology and Advanced Engineering, ISSN 22502459, Volume4, Issue 3, March 2014. 